\title{
Т.А. Сироткина
}

\section{«В ЕДИНСТВЕ И МНОГООБРАЗИИ ХУДОЖЕСТВЕННЫХ ТРАДИЦИЙ» (РЕЦЕНЗИЯ НА КН.: ИСТОРИЯ ЛИТЕРАТУРЫ УРАЛА. ХІХ ВЕК: В 2 КН. / ПОД РЕД. Е.К. СОЗИНОЙ. М.: ИЗД. ДОМ ЯСК, 2020)}

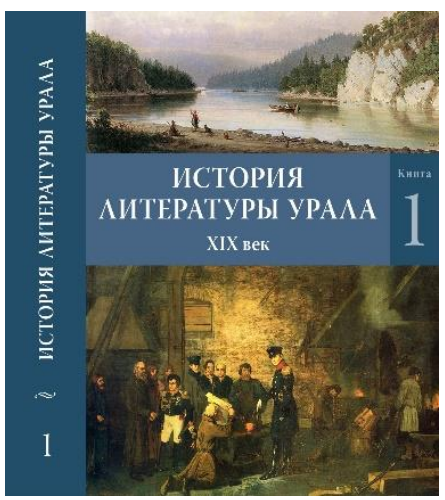

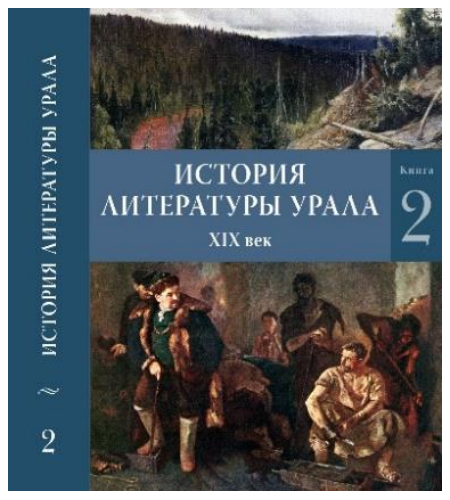

Аннотация. Представлена рецензия на второй том «Истории литературы Урала», которая является исследованием уральской литературы $X I X$ в.

Ключевые слова: литература Урала, история литературы, уральские писатели.

Часто приходится сталкиваться с мнением исследователей о том, что в истории региональных литератур существует множество лакун. Еще совсем недавно это можно было сказать и о литературе Урала. Выход в свет первого тома «Истории литературы Урала» [1] дал литературоведам повод надеяться, что «с полной реализацией проекта академической литературы Урала многие ее белые пятна будут закрыты» [2. С. 179]. Представляется, что как минимум наполовину надежды эти уже оправдались, поскольку в 2021 г. увидел свет второй том «Истории литературы Урала» [3] - многостраничное издание в двух книгах, итог многолетних трудов коллектива российских литературоведов под редакцией доктора филологических наук, профессора Елены Константиновны Созиной.

Чрезвычайно продуктивной представляется идея «скрещивания региональных и национальных пород на почве литературы определенного региона» [3. С. 32], проповедуемая составителями издания. 
Своеобразие данной книги, как они пишут во введении к ней, состоит «в том, что история региональной русской литературы объединена здесь с историями ряда национальных литератур народов, издревле проживающих на Урале и обладающих в пределах региона культурной, а сегодня и административной автономией» [Там же. С. 26].

Справедливо подчеркивается авторами «социальный» характер литературы горнозаводского Урала в XIX в. «Специфика Урала, - пишут они, - во многом определила характерную особенность, присущую его культуре, искусству, словесности, - социальность, подчас даже социологичность, проявляющуюся в том числе и в сознании жителей региона - в их постоянном и настойчивом интересе к делам общественным, в позиционировании себя как края рабочего, коллективистского, сплоченного общей судьбой и общими интересами» [Там же. С. 36].

В главе 1 - «Русская литература Урала первой половины XIX века» - представлено творчество таких авторов, как Т.С. Беляев, П.М. Кудряшов, А.П. Крюкова, П.П. Ершов, Т.С. Аксаков и др. Также в ней рассматриваются уральский период жизни и творчества В.И. Даля и чрезвычайно интересная как для опытных, так и для начинающих литературоведов тема «А.С. Пушкин и Урал». Включение данного материала в курс истории уральской литературы представляется логичным и обоснованным, поскольку, по справедливому замечанию регионалистов, одним из основных направлений литературного краеведения является «исследование взаимоотношений писателя и края», в рамках которого предполагается «изучение пребывания писателя в крае и значение этого для его творчества» [4. С. 80].

История литературы многонационального региона немыслима без подробного анализа национальных литератур, составляющих ее. Глава 2 - «Развитие башкирской литературы» - являет собой пример такого анализа. Поскольку в текстах национальных авторов ярко репрезентируются особенности культуры, быта, традиций, мировосприятия народа, то исследование текстов национальных авторов, безусловно, является важным источником изучения этнического самосознания представителей башкирского этноса, населяющих в XIX в. территорию Урала.

Не менее значимой составляющей литературы Урала является литература коми, которая, по наблюдениям исследователей, тесно связана с фольклором, отражает своеобразие окружающей среды, фор- 
мирующей характеры героев, мифопоэтические представления народа коми [5]. В главе 3 - «Формирование литературной традиции в Коми крае» - рассматривается роль письменности в становлении литературной традиции коми, описываются жанровые модели документально-художественной словесности Коми края в XIX в., анализируется творчество первых коми-поэтов, а также писателей И.А. Куратова, Г.С. Лыткина, Ф.А. Арсеньева.

В главе 4 - «Формирование литературной традиции в Удмуртии» рассмотрена история удмуртской литературы, представлявшая ко второй половине XIX в., как отмечают исследователи, «сочетание творчества местных русских авторов, произведений политических ссыльных и сочинений зарождавшейся русской интеллигенции» [3. С. 395]. В данной главе показана роль переводов духовной и учебной литературы в становлении литературной традиции в Удмуртии, подробно рассмотрены переводческая деятельность В.А. Ислентьева, творчество Г.Е. Верещагина.

Глава 5 - «Ссыльные писатели на Урале (первая половина XIX века)» - раскрывает читателям страницы жизни и творчества таких литераторов-декабристов, как Н.И. Лорер, В.П. Ивашев, Н.А. Чижов, А.П. Барятинский, Н.С. и П.С. Бобрищевы-Пушкины, А.И. Одоевский, С.Д. Нечаев, В.К. Кюхельбекер. Авторы описывают литературный быт ссыльных поляков, подробно анализируют творчество Т.Г. Шевченко, Л.М. Михайлова, А.Н. Плещеева.

Пристальное внимание авторов книги уделено жанру травелога. Глава 6 - «Урал в записках путешественников. Литературное освоение региона в путевой прозе XIX века» - представляет собой своеобразную литературную карту маршрутов путешествий писателей по Уралу, фокусными точками которой являются воспоминания об этих местах Ф.Ф. Вигеля, В.А. Жуковского, П.И. Мельникова-Печерского, Д.Н. Мамина-Сибиряка, А.П. Чехова и многих других авторов, позволяющие «увидеть основные этапы становления уральского ландшафта русской культуры в его развитии от негативной идентификации к образу самобытного и семиотически насыщенного пространства» [Там же. С. 522].

Неоспоримой заслугой авторов издания является учет ими при составлении книги таких неотъемлемых составляющих литературной среды, как местный театр и библиотеки. В главе 7 - «История театрального дела и драматургия на Урале» - рассматриваются значение 
крепостных театров региона в развитии театрального дела, роль первых антреприз в становлении региональной драматургии, история развития театра в Перми и Екатеринбурге в последние десятилетия XIX в.

Периодическая печать Урала второй половины XIX века подробно рассмотрена в главе 9. Отмечая тесную взаимосвязь литературной жизни региона с историей региональной журналистики [3. С. 723], авторы книги детально описывают функционирование таких периодических изданий, как «Пермские губернские ведомости», «Оренбургские губернские ведомости», «Тобольские губернские ведомости», «Екатеринбургская неделя».

Глава 10 - «Развитие литературы региона во второй половине XIX века»- представляет собой описание литературной жизни Пермской и Тобольской губерний, а также Оренбургского края в указанный период. В отдельной, 11-й главе, представлено творчество Д.Н. Мамина-Сибиряка.

Нельзя не сказать о том, что издание великолепно отредактировано (редактирование материалов осуществлялось кандидатом филологических наук Т.А. Арсеновой) и проиллюстрировано (подбор иллюстративного материала производился кандидатом искусствоведения Е.П. Алексеевым).

Таким образом, благодаря усилиям авторов, мы имеем дело с системным трудом по истории уральской литературы XIX в., к которому, безусловно, будут обращаться как начинающие исследователи, так и ученые-специалисты.

\section{Лuтература}

1. История литературы Урала. Конец XIV - XVIII в. / гл. ред. В.В. Блажес, Е.К. Созина. М. : Языки славянской культуры, 2012. 608 с.

2. Абашев В.В., Абашева М.П. История Урала в истории словесности (рецензия на: История литературы Урала. Конец XIV - XVIII в. (гл. ред. В.В. Блажес, Е.К. Созина). М.: Языки славянской культуры, 2012) // Вестник Пермского университета. Сер. История. 2013. Вып. 2 (22). С. 179-181.

3. История литературы Урала. ХІХ век : в 2 кн. / под ред. Е.К. Созиной. М. : Изд. Дом ЯСК, 2020. 1440 с.

4. Дрондина Н.Г. Литературное краеведение в процессе воспроизводства культуры в регионе // Регионология. 2008. № 3. С. 80-85.

5. Пахорукова В.В. Пути и проблемы развития коми-пермяцкой прозы. Л. : Наука, 1977. 174 с. 
"In the Unity and Diversity of Artistic Traditions" (Book Review: Sozina, E.K. (Ed.) (2020) Istoriya Literatury Urala. XIX Vek: V 2 Kn. [A History of Ural Literature. 19th Century: In 2 Books]. Moscow: LRC)

Tekst. Kniga. Knigoizdanie - Text. Book. Publishing, 2021, 25, pp. 182-187

DOI: $10.17223 / 23062061 / 25 / 11$

Tatyana A. Sirotkina, Surgut State Pedagogical University (Surgut, Russian Federation). E-mail: sirotkina71@mail.ru

Keywords: literature of the Urals, history of literature, Ural writers.

One often comes across the opinion of researchers that there are many lacunae in the history of regional literatures. Until quite recently, this could be said about the literature of the Urals. The publication of the first volume of A History of Ural Literature gives literary scholars a reason to hope that, with the full implementation of the project of the Ural academic literature, many of its blank spots will be closed. It seems that at least half of these hopes have already been justified since, in 2021, the second volume of A History of the Literature of the Urals was published. It is a multi-page publication in two books, the result of many years of work by a team of Russian literary critics. The volume's editor-in-chief is Doctor of Philology, Professor Elena Konstantinovna Sozina The idea of "crossing regional and national breeds on the basis of the literature of a certain region", preached by the book compilers, seems extremely productive. The peculiarity of this book, as the introduction claims, is "that the history of regional Russian literature is united here with the histories of a number of national literatures of peoples who have lived in the Urals since ancient times and have a cultural, and now also administrative, autonomy within the region". The book's authors rightly emphasize the "social" character of the literature of the mining Urals in the nineteenth century. They write that the specificity of the Urals largely determined the characteristic feature inherent in its culture, art, literature: sociality, sometimes even sociology, manifested, among other things, in the minds of the inhabitants of the region, in their constant and persistent interest in public affairs, in their positioning of the region as working, collectivist, united by a common destiny and common interests. The publication is superbly prepared (the materials were edited by the Cand. Sci. (Philology) T.A. Arsenova) and illustrated (the selection of illustrative material was made by the Cand. Sci. (Art History) E.P. Alekseev). Thus, thanks to the efforts of the authors, we are dealing with a systematic work on the history of the Ural literature of the 19th century, which will undoubtedly be addressed by both novice and expert researchers.

\section{References}

1. Blazhes, V.V. \& Sozina, E.K. (2012) Istoriya literatury Urala. Konets XIV XVIII v. [History of Ural literature. The late 14th - 18th centuries]. Moscow: Yazyki slavyanskoy kul'tury. 
2. Abashev, V.V. \& Abasheva, M.P. (2013) Istoriya Urala v istorii slovesnosti [History of the Urals in the history of literature]. Vestnik Permskogo universiteta. Ser. Istoriya - Perm University Herald. History. 2(22). pp. 179-181. (In Russian).

3. Sozina, E.K. (ed.) (2020) Istoriya literatury Urala. XIX vek: $v 2 \mathrm{kn}$. [A History of Ural Literature. 19th Century: In 2 Books]. Moscow: Yazyki slavyanskoy kul'tury.

4. Drondina, N.G. (2008) Literaturnoe kraevedenie v protsesse vosproizvodstva kul'tury $\mathrm{v}$ regione [Literary study of local lore in the process of culture reproduction in the region]. Regionologiya. 3. pp. 80-85.

5. Pakhorukova, V.V. (1977) Puti i problemy razvitiya komi-permyatskoy prozy [Ways and problems of the development of Komi-Perm prose]. Leningrad: Nauka. 